\title{
SPIDERS COLLECTED IN RESIDENCES FROM MUNICIPALITIES OF BARBALHA, CRATO AND JUAZEIRO DO NORTE, STATE OF CEARÁ, BRAZIL
}

\author{
Raul Azevedo1*, Larissa N. Silva1, Francisco B. Silva Júnior1, Francisco R. de Azevedo, José M. de A. \\ Carvalho Júnior² \& Joseph A. D. de C. Sobreira ${ }^{3}$
}

\author{
${ }^{1}$ Laboratório de Entomologia,Universidade Federal do Cariri - UFCA. Crato, Ceará, Brazil. \\ 2Instituto Federal de Educação, Ciência e Tecnologia do Ceará - IFCE.Acaraú, Ceará, Brazil. \\ ${ }^{3}$ Centro de Educação Rural Pedro Raimundo da Cruz - Missão Velha, Ceará, Brazil.
}

*Corresponding author: raulbiologo@gmail.com

\begin{abstract}
The present work reports the fauna of spiders collected in residences of the municipalities of Barbalha, Crato and Juazeiro do Norte, in the state of Ceará, Brazil. Ten random neighborhoods were selected in each municipality, including central and border neighborhoods. In each neighborhood, 10 houses were randomly selected, totalizing 30 neighborhoods and 300 houses surveyed. Manual collections were carried out in the interior and exterior of the residences, without replication during the months. Pholcidae was the richest family (3 species). Smeringopus pallidus (Blackwall, 1858) was the unique species that occurred in all municipalities sampled. Species like Sicarius cariri Magalhaes, Brescovit \& Santos, 2013 and Leprolochus oeiras Lise, 1994 were found inside residences by the first time.
\end{abstract}

Key words: Araneae, Arthropds, Buildings, Araripe Plateau.

\section{RESUMEN}

Arañas recolectadas en residencias de los municipios de Barbalha, Crato y Juazeiro do Norte, CE, Brasil. El presente trabajo reporta la fauna de arañas recogidas en residencias de los municipios de Barbalha, Crato y Juazeiro do Norte. Se seleccionaron 10 barrios aleatorios en cada municipio, contemplando barrios centrales y limítrofes. En cada barrio, 10 casas fueron seleccionadas aleatoriamente, totalizando 30 barrios y 300 casas visitadas. Se realizaron colectas manuales en el interior y exterior de las residencias, sin replicación a lo largo de los meses. Pholcidae presentó mayor riqueza de especies $(S=3)$. Smeringopus pallidus (Blackwall, 1858) fue la única especie que ocurrió en los tres municipios muestreados. Especies como Sicarius cariri Magalhaes, Brescovit \& Santos, 2013 y Leprolochus oeiras Lise, 1994 fueron encontradas por primera vez en el interior de las residencias.

Palabras Clave: Araneae, Artrópodos, edificios, Chapada del Araripe.

\section{INTRODUCTION}

Urban environments are characterized by intensive human activity (Mclntyre, 2000) and this is one of the most problems for biodiversity conservation (McKinney, 2002). Environmental changes caused by urbanization affect organisms in different ways (Lutinski et al., 2013). Therefore is critical to understand if different taxa and how it will respond to alterations in landscape structure (Shochat et al., 2004; Magura et al., 2008).

Spiders are abundant and dominant components of the arthropod predatory guild in most communities (Wise, 1993), and in some cases, they are influenced positively by urbanization and habitat fragmentation. Miyashita et al. (1998) observed a positive relation between forest fragment sizes and spiders species density and Magura et al. (2010) also collected more species in urban areas when associated to urbanization gradient.

As a result of urbanization process, many insects and arachnids live with human been inside their residences (Mourier et al., 1979; Mclntyre, 2000; DuránBarrón et al., 2009). One of the reasons why spiders inhabit human residences is the absence of predators and the presence of food resource, like insects (Jímenez, 1998). But how urbanization process affects spiders communities is poorly known (Shochat et al., 2004).

Spiders from urban residences were studied along the Americas: in Canada (Williams, 1999); Cuba (Armas, 2003); Mexico (Jiménez, 1998; Cupul-Magaña \& Navarrete-Heredia, 2008; Durán Barrón et al., 2009) and USA (Cutler, 1973; Kaston, 1983; Guarisco, 1999). For Brazil, Brazil et al. (2005) reports the occurrence of 13 synantropic species from residences; Fischer \& Vasconcellos-Neto (2005) analyzed microhabitats indoor and outdoor residences occupied by Loxosceles intermedia Mello-Leitão, 1934 and Loxosceles laeta (Nicolet, 1849) (Araneae: Sicariidae) in Curitiba, state of Paraná, Brazil. Fischer et al. (2011) studied the spider fauna associated to Sicariidae inside residences. Brescovit et al. (2011) compiled a species list of 875 species reported for state of São Paulo and highlight the occurrence of 70 synantropic species. 


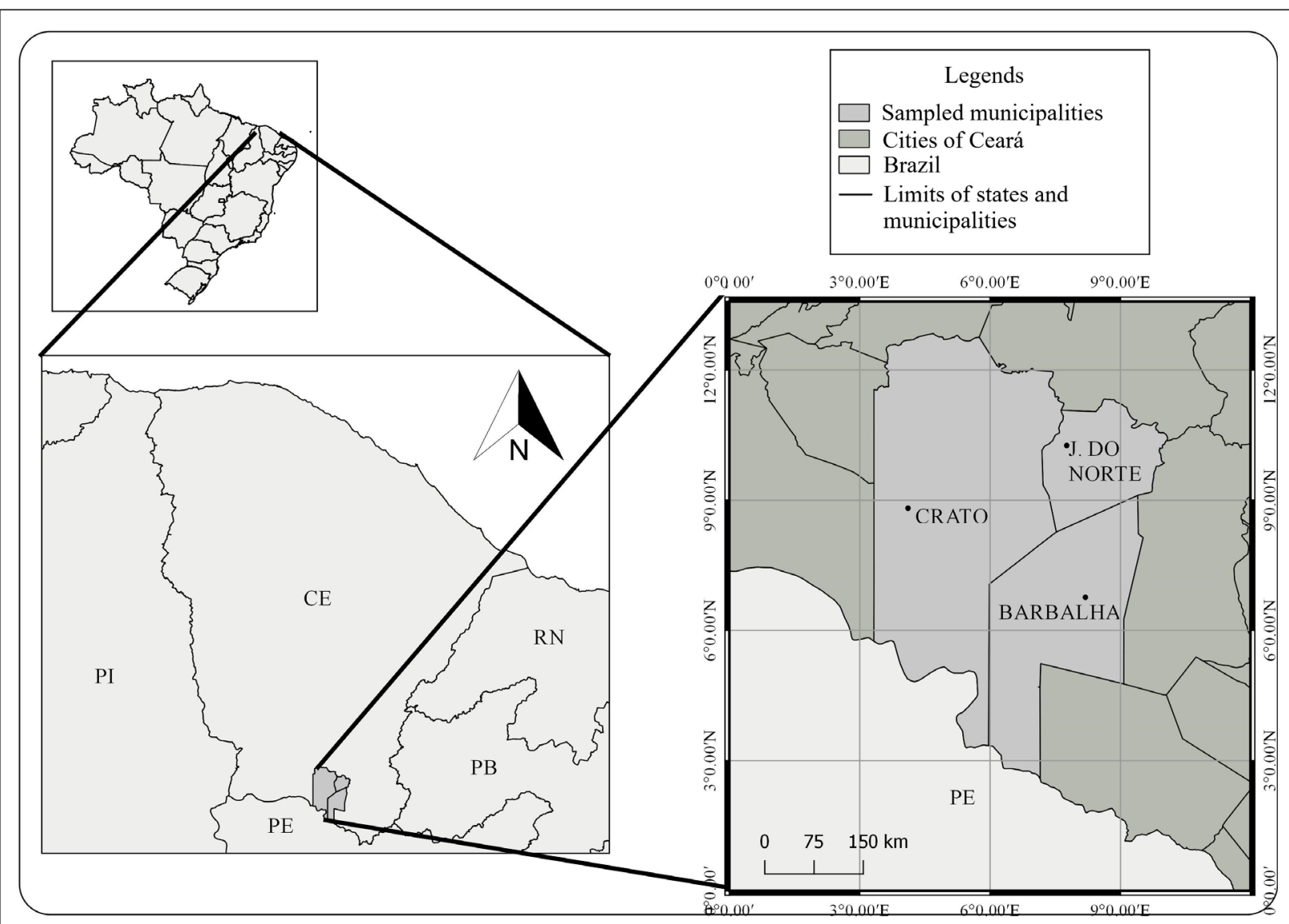

Fig. 1. Municipality of Barbalha, Crato and Juazeiro do Norte, State of Ceará, Brazil.

The cities of Barbalha, Crato and Juazeiro do Norte are the most populous municipalities of the Araripe Plateau, South of State of Ceará (Ipece, 2007), Northeast, Brazil. Some authors have described some species from these municipalities, e.g. Soesilarishius cearensis Ruiz, 2013 (Salticidae) (Ruiz, 2013) and Micropholcus crato Huber, Carvalho \& Benjamin, 2014 (Pholcidae), (Huber et al., 2014). More recently, a general arachnid species list from Araripe Plateau was registered by Azevedo et al. (2016) composed by 68 species, which 53 species are spiders/morphospecies belonging to 25 families.

The objective of this work is present a species list of spiders found inside residences from municipalities of Barbalha, Crato and Juazeiro do Norte.

\section{MATERIALS AND METHODS}

The study was done in municipalities of Barbalha, Crato and Juazeiro do Norte (Fig. 1) from March to December 2017. From each municipality, 10 districts were selected and 10 houses were randomly chosen in each district, totalizing 30 districts and 300 houses visited.

Manual and diurnal collections were performed inside and outside residences (Brazil et al., 2005; Fischer et al., 2009), during 20 minutes/month and each residence was visited only one time during all sample period. Each residence was examined inside and outside (walls and areas attached to the house, like area, edge windows and under washing sinks).

All material collected was examinated at the Laboratório de Entomologia of Universidade Federal do Cariri - UFCA, preserved in $70 \%$ ethanol and deposited in the Arachnological Collection of Instituto Butantan São Paulo (IBSP, Curator: A.D. Brescovit).

The specimens were identified using the following keys: Pholcidae (Huber, 2000; 2012; Aharon et al., 2017); Sicariidae (Magalhães et al., 2013); Uloboridae (Grismado, 2008); Zodariidae (Lise, 1994), also by comparation with material housed in the IBSP collection. 
Table 1. Species composition found on residences by municipalities Barbalha, Crato and Juazeiro do Norte, from march to december 2017.

\begin{tabular}{|c|c|c|}
\hline Taxon & Municipality & District \\
\hline \multicolumn{3}{|l|}{ PHOLCIDAE } \\
\hline Artema atlanta Walckenaer, 1837 & Crato & Vila Alta \\
\hline \multirow[t]{3}{*}{ Smeringopus pallidus (Blackwall, 1858) } & Barbalha & Bela Vista, Bulandeira \\
\hline & Crato & $\begin{array}{c}\text { Caixa d'água, Granjeiro, Muriti, } \\
\text { Pimenta, São Miguel, Seminário, } \\
\text { Sossego, Vila Alta }\end{array}$ \\
\hline & Juazeiro do Norte & Salesianos \\
\hline Metagonia sp. & Crato & $\begin{array}{c}\text { Caixa d'água, Granjeiro, Lameiro, } \\
\text { Pimenta, São Miguel, Seminário, } \\
\text { Sossego, Vila Alta }\end{array}$ \\
\hline \multicolumn{3}{|l|}{ SICARIIDAE } \\
\hline Sicarius cariri Magalhães, Santos, Brescovit 2013 & Crato & Lameiro \\
\hline Loxosceles amazonica (Gertsch, 1967) & Crato & Barro Branco \\
\hline \multicolumn{3}{|l|}{ ULOBORIDAE } \\
\hline Zosis geniculata (Olivier, 1789) & $\begin{array}{c}\text { Crato } \\
\text { Juazeiro do Norte }\end{array}$ & $\begin{array}{l}\text { Muriti, Vila Alta } \\
\text { Jardim Gonzaga }\end{array}$ \\
\hline \multicolumn{3}{|l|}{ ZoDARIIIAE } \\
\hline Leprolochus oeiras Lise 1994 & Juazeiro do Norte & Planalto \\
\hline
\end{tabular}

\section{RESULTS AND DISCUSSION}

Seven urban spiders species belonging to three families (Table 1) were collected (Fig. 2). Pholcidae was the richest family. Smeringopus pallidus occurred in all municipalities sampled. Artema atlanta and Sicarius cariri occurred only in the municipality of Crato and Leprolochus oeiras occurred only in the municipality of Juazeiro do Norte.

The genus Smeringopus has pholcids relatively large, with elongated abdomen and restrict to Africa. Smeringopus pallidus is one of the exceptions to genus distribution been considered a Pantropical species (Huber, 2012). Smeringopus natalensis Lawrence, 1947 is related as an introduced species in Australia, probably result from misidentification of $S$. pallidus for more details, see Huber (2001). In Brazil, S. pallidus is considered a common and synanthropic species inside residences (Mello-Leitão, 1918; Brazil et al., 2005; Brescovit et al., 2011). Along South America, it's reported to Ecuador continental (Duperré, 2017), Paraguay (Kochalka et al., 1996), to north of Chile (Taucare-Ríos, 2012) and is considered one of the less abundant resident spider species (Taucare-Ríos et al., 2013).
Artema atlanta is an introduced species which records initially refers it's occurrence from United States to Paraguay (Brignoli, 1981). Over time for now, also with reports for Cuba (Gonzalez, 1996), Venezuela (Colmenares-García, 2008) and Argentina (Huber, 2014), for more details, see Aharon et al. (2017). This species inhabit dark and sheltered cavities like caves and human buildings, like basements (Huber \& Kwapong, 2013; Aharon, 2016). A. atlanta was considered very common along the Brazilian Coast (Mello-Leitão, 1918), however, nowadays it's occurrence had decreased along Brazilian Coast, mainly from littoral of state of Rio Grande do Sul to litoral of state of Rio Grande do Norte (Huber, unpublished data). This species has a worldwide distribution, probably due human-aided transport, althought is not clear why this species has spread all over the world (Aharon et al., 2017).

Loxosceles amazonica is a species already reported for residences in state of Ceará, in municipality of Sobral, north of state (Azevedo et al., 2014). Sicarius cariri is one of the six-eyed sand spiders from the Brazilian Caatinga (Magalhães et al., 2013) and it's also already reported to Araripe Plateau (Azevedo et al., 2016). Its occurrence inside a residence probably 
is occasional and can be attributed to fact of be closeness to a basis of Araripe Plateau, also urbanization process associated to local deforestation (Carvalho \& Ribeiro, 2006).

Leprolochus oeiras is also already reported for Araripe Plateau (Azevedo et al., 2016). The genus Leprolochus can be found from dry to wet environments (Jocqué, 1988), from Panamá to Argentina (World Spider Catalogue, 2018). Althought be noted that Leprolochus species responses to anthropic disturbance (Torres et al., 2016), the presence of $L$. oeiras in a residence probably consist on an occasional recorder, and this unique record does not allow to make assumptions about its occurrence associated with residences.

\section{CONCLUSIONS}

Pholcidae are more distributed along the neighbors of municipality of Barbalha, Crato and Juazeiro do Norte, and Smeringopus pallidus and Metagonia sp. were present in all districts from municipality of Crato.

Sicarius cariri and Leprolochus oeiras constitutes species related to local, and more sample process should be conducted aiming get more data about its distribution and colonization on residences.

This research results the first species list from residences from state of Ceará. They also increase the number of species for Araripe Plateau therefore contributing to knowledge of local spider fauna.

\section{ACKNLOWDEGEMENTS}

The authors want to thank Dr. Antonio Domingos Brescovit (IBSP) for species identification.

\section{REFERENCES}

Aharon S. 2016. Ecology and Taxonomy of the Family Pholcidae in Israel: Species Richness, Geographic Distributions and Taxonomical Revision of the Genus Artema (Pholcidae, Araneae). MSc thesis, Ben-Gurion University of the Negev, Israel. Available from http:// nnhc.huji.ac.il/wp-content/uploads/2017/01/ aharonshlomi.pdf [accessed 17 Sep. 2018].

Aharon S., Huber B.A. \& E.G. Regev. 2017. Daddylong-leg giants: revision of the spider genus Artema Walckenaer, 1837 (Araneae, Pholcidae). European Journal of Taxonomy, 376: 1-57.

Armas, L.F. 2003. Notas sobre los arácnidos de mi casa (Chelicerata, Arachnida). Revista Ibérica de Aracnología, 8: 143-149.

Azevedo R., Texeira P.M.S., Siqueira R.C.L. \& A.D. Brescovit. 2014. New record and distribution of Loxosceles amazonica Gertsch, 1967 (Araneae: Sicariidae) in the State of Ceará, Brazil. Check List, 10(1): 207-208.

Azevedo R., Moura E.S., Lopes A.S., Carvalho L.S., Dias S.C. \& A.D. Brescovit. 2016. Arachnids from Araripe Plateau, Ceará, Brazil. CheckList, 12(4): 1920.

Brazil T.K., Silva L.M.A., Leite C.M.P., Silva R.M.L., Peres, M.C.L. \& A.D. Brescovit. 2005. Aranhas sinantrópicas em três bairros da cidade de Salvador, Bahía, Brasil (Arachnida, Araneae). Biota Neotropica, 5(1a): 163-169.

Brescovit A.D., Oliveira U. \& A.J. Santos. 2011. Aranhas (Araneae, Arachnida) do Estado de São Paulo, Brasil: diversidade, esforço amostral e estado do conhecimento. Biota Neotropica, 11: 1-32.

Brignoli P.M. 1981. Studies on the Pholcidae, I. Notes on Genera Artema and Physocyclus (Araneae).

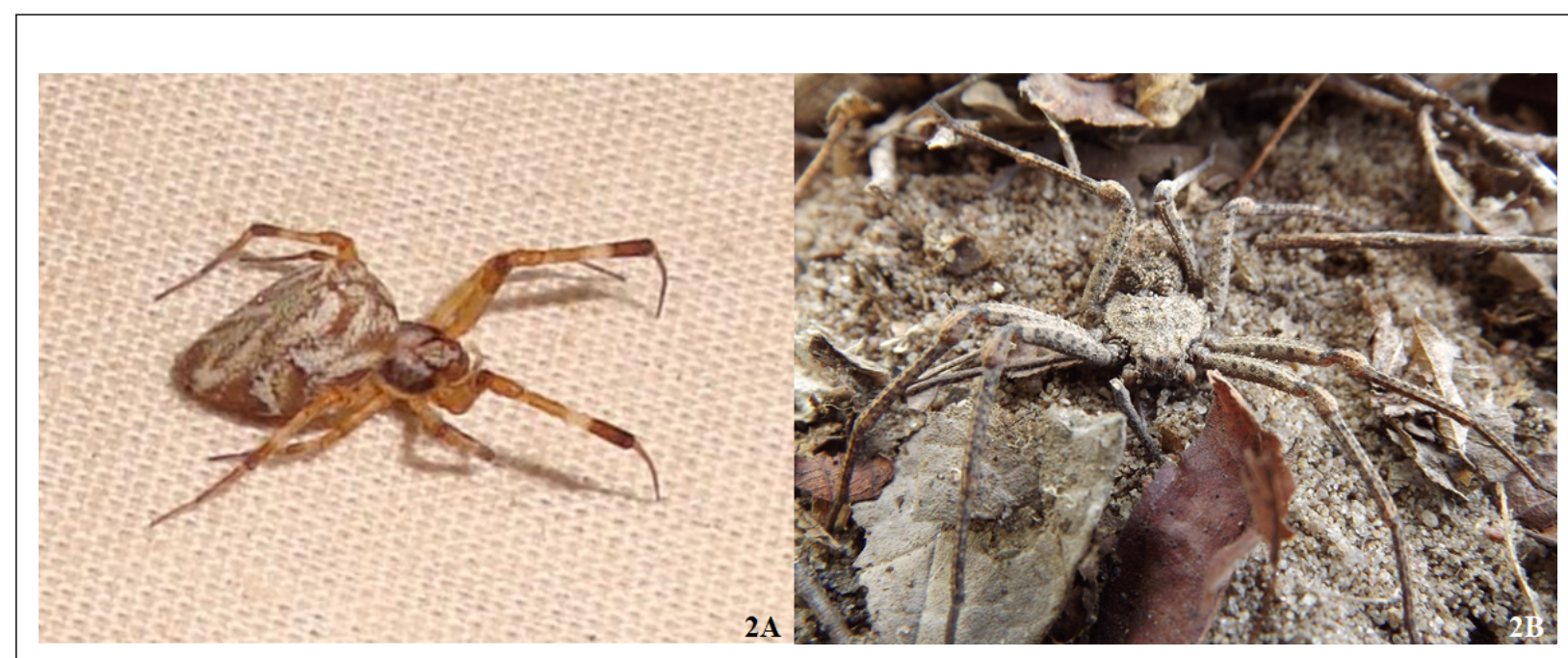

Fig. 2. Species sampled on residences of municipalities Barbalha, Crato e Juazeiro do Norte. 2A: Zosis geniculata, credits: Antonio Brescovit. 2B: Sicarius cariri, credits: Ivan Magalhães. 
Bulletin of the American Museum of Natural History, 170: 1-11.

Carvalho S.M \& S.C. Ribeiro. 2006. Áreas de risco urbanas na cidade do Crato/Ce - Estudo das suas formas de relevo e declividades. En: VI Simpósio de Geomorfologia. Geomorfologia Tropical e Subtropical: processos, métodos e técnicas. Goiania, Goiás, Brasil. pp. 1-9.

Colmenares-García P.A. 2008. Tres nuevos registros para la araneofauna Venezolana (Arachnida, Araneae, Pholcidae). Boletin del Centro de Investigaciones Biológicas de la Universidad del Zulia, 42: 85-92.

Cupul-Magaña F. \& J.L. Navarrete-Heredia. 2008. Artropodofauna de las viviendas de Puerto Vallarta, Jalisco, México. Ecología Aplicada, 7: 187-190.

Cutler B. 1973. Synanthropic spiders Araneae of the twin cities area. Journal of the Minnesota Academy of Science, 39: 38-39.

Duperré N. 2017. Arachnids of Ecuador. Available from:< http://aracnidos.otonga.org/index.html>. [accessed 17 Jan. 2019].

Durán-Barrón C.G, Francke O.F. \& T.M. Pérez-Ortiz. 2009. Diversidad de arañas (Arachnida: Araneae) asociadas a viviendas de la ciudad de México (Área metropolitana). Revista Mexicana de Biodiversidad, 80: 55-69.

Fischer M.L. \& J. Vasconcellos-Neto. 2005. Microhabitats occupied by Loxosceles intermedia and Loxosceles laeta (Araneae: Sicariidae) in Curitiba, Paraná, Brazil. Journal of Medical Entomology, 42: 756-765.

Fischer M.L., Bazilio S., Dos Santos T.V.B. \& C.B. Grosskopf. 2009. Diagnóstico da ocorrência de aranhas do gênero Loxosceles Heineken e Lowe, 1832 (Araneae, Sicariidae) no município de União da Vitória, Paraná. Biotemas, 22(1): 155-159.

Fischer M.L., Grosskopf C.B., Bazílio S. \& J. Ricetti. 2011. Araneofauna sinantrópica associada com a família Sicariidae no município de União da Vitória Paraná, Brasil. Sitientibus série Ciências Biológicas, 11(1): 48-56.

González, A.P. 1996. Sobre la ausencia del género Crossopriza (Araneae: Pholcidae) en Cuba, con una nueva sinonimia para Artema atlanta Walckenaer, 1837. Caribbean Journal of Science, 32: 431-432.

Grismado C.J. 2008. Uloboridae. En: Claps L.E., Debandi G. \& S. Roig (Eds.) Biodiversidad de Artrópodos Argentinos pp. 97-103. Buenos Aires, Sociedad Entomológica Argentina.

Guarisco, H. 1999. House spiders of Kansas. Journal of Arachnology, 27: 217-221.

Huber B.A. 2000. New World pholcid spiders (Araneae: Pholcidae): A revision at generic level. Bulletin of the American Museum of Natural History,
254: 1-348.

Huber B.A. 2001. The pholcids of Australia (Araneae; Pholcidae): taxonomy, biogeography, and relationships. Bulletin of the American Museum of Natural History, 260: 1-144.

Huber B.A. 2012. Revision and cladistic analysis of the Afrotropical endemic genus Smeringopus Simon, 1890 (Araneae: Pholcidae). Zootaxa, 3461: 1-138.

Huber B.A. 2014. Pholcidae. En: Claps L.E., Debandi G. \& S. Roig-Juñent (Eds.) Biodiversidad de Artrópodos Argentinos, vol. 3. pp. 37-46. Sociedad Entomológica Argentina, Mendoza.

Huber B.A \& P. Kwapong. 2013. West African pholcid spiders: an overview, with descriptions of five new species (Araneae, Pholcidae). European Journal of Taxonomy, 59:1-44.

Huber B.A, Carvalho L.S. \& S.P. Benjamin. 2014. On the New World spiders previously misplaced in Leptopholcus: molecular and morphological analyses and descriptions of four new species (Araneae: Pholcidae). Invertebrates Systematics, 28: 432-450.

Ipece. 2007. O Ceará em mapas. Available from:<http:/ /www2.ipece.ce.gov.br/atlas/>. [accessed 24 Sep. 2018].

Jimenez M.L. 1998. Aracnofauna asociada a las viviendas de la ciudad de La Paz, B. C. S., México. Folia Entomologica Mexicana, 102: 110.

Jocqué R. 1988. An updating of the genus Leprolochus (Araneae: Zodariidae). Studies on Neotropical Fauna and Environment, 23(2): 77-87.

Kaston B.J. 1983. Synanthropic spiders. En: Frankie G.W. \& Koehler C.S. (Eds.) Urban entomology: interdisciplinary perspectives, pp. 221-245. Praeger, Nueva York.

Kochalka J., Torres D., Garcete B. \& C. Aguilera.1996. Lista de invertebrados de Paraguay pertenecientes a las colecciones de flora y fauna del museo de historia natural del Paraguay. En: Romero M. (Ed.) Colecciones de flora y fauna del Museo Nacional de Historia Natural del Paraguay, pp. 69-283. Ministerio de Agricultura y Ganadería, Asunción.

Lise A.A. 1994. Description of three new species of Leprolochus Simon and additional illustrations of L. spinifrons Simon and L. birabeni Mello-Leitão (Araneae, Zodariidae). Biociências, 2: 99-117.

Lutinski J.A., Lopes B.C. \& A.B DeMorais. 2013. Diversidade de formigas urbanas (Hymenoptera: Formicidae) de dez cidades do sul do Brasil Biota Neotropica, 13 (3): 332-342.

Magalhães I.L.F., Brescovit A.D. \& A.J. Santos. 2013. The six-eyed sand spiders of the genus Sicarius (Araneae: Haplogynae: Sicariidae) from the Brazilian Caatinga. Zootaxa, 3599 (2): 101-135. Magura T., Horváth R. \& B. Tóthmérész. 2010. Effects 
of urbanization on ground-dwelling spiders in forest patches, in Hungary. Landscape Ecology, 25: 621-629.

Magura T., Tóthmérész B., Hornung E. \& R. Horváth. 2008. Urbanisation and ground-dwelling invertebrates. En: Wagner L.N. (Ed.). Urbanization: 21st century issues and challenges, pp. 213-225. Nova Science Publishers, Nueva York.

Mclntyre N.E. 2000. Ecology of urban arthropods: a review and call to action. Annals of the Entomological Society of America, 93: 825-835.

McKinney M.L. 2002. Urbanization, biodiversity, and conservation. BioScience, 52(10): 883-890.

Mello-Leitão C.F. 1918. Scytodidas e Pholcidas do Brasil. Revista do Museu Paulista, 10: 85-144.

Miyashita T., Shinkai A. \& T. Chida. 1998. The effect of forest fragmentation on web spider communities in urban areas. Biological Conservation, 86: 357-364.

Mourier H., Winding O. \& E. Sunsen. 1979. Guía de los animales parásitos de nuestras casas. Omega, Barcelona, 224pp.

Ruiz G.R.S. 2013. Nine new species of Soesilarishius from Brazil (Araneae: Salticidae: Euophryinae). Zootaxa, 3664(4): 586-600.

Shochat E., Stefanov W.L., Whitehouse M.E. \& S.H. Faeth. 2004. Urbanization and spider diversity: influences of human modification of habitat structure and productivity. Ecological Applications, 1(4): 268-280.

Taucare-Ríos, A. 2012. Primeros registros de Smeringopus pallidus en Chile (Araneae: Pholcidae). Revista Chilena de Entomología, 37: 81-85.

Taucare-Ríos A., Brescovit A.D. \& M. Canals. 2013.Synanthropic Spiders (Arachnida: Araneae) from Chile. Revista Ibérica de Aracnología, 23: 49-56.

Torres V.M., González-Reyes A.X., Rodriguez-Artigas S.M. \& J.A. Corronca. 2016. Efectos del disturbio antrópico sobre las poblaciones de Leprolochus birabeni (Araneae, Zodariidae) en el Chaco Seco del noroeste de Argentina. Iheringia, Série Zoologia, 106: e2016009.

Williams, H. 1999. Spiders in houses. Newsletter of the British Arachnological Society, 84: 10-11.

World Spider Catalog. 2018. Natural History Museum Bern. Available at: <http://wsc.nmbe.chhttp:// wsc.nmbe.ch>.Acessed on: 2018-08-07.

Wise D.H. 1993. Spiders in ecological webs. Cambridge University Press, New York, New York. 344 pp.

Fecha de Recepción: 15 de octubre de 2018 Fecha de Aceptación: 9 de abril de 2019 